\title{
Male gonadal function, prolactin secretion and lactotroph population in an experimental model of cirrhosis
}

P.H. Gonzales ${ }^{1}$, C.R. Rhoden², C. Luz ${ }^{4}$, G. Corrêa ${ }^{1}$, L.M. Barbosa-Coutinho ${ }^{3}$ and M.C. Oliveira ${ }^{1}$

\author{
'Departamento de Endocrinologia, '2Departamento de Farmacologia, \\ ${ }^{3}$ Departamento de Patologia, Fundação Faculdade Federal de Ciências Médicas de \\ Porto Alegre, Porto Alegre, RS, Brasil \\ ${ }^{4}$ Complexo Hospitalar da Santa Casa de Porto Alegre, Porto Alegre, RS, Brasil
}

\author{
Correspondence \\ M.C. Oliveira \\ Rua Dona Mimi Moro, 40 \\ 90480-050 Porto Alegre, RS \\ Brasil \\ Fax: +55-51-3328-6761 \\ E-mail: mco@portoweb.com.br
}

Received January 18, 2006

Accepted June 12, 2007

\begin{abstract}
Liver cirrhosis, a highly prevalent chronic disease, is frequently associated with endocrine dysfunctions, notably in the gonadal axis. We evaluated lactotroph population by immunohistochemistry, gonadotropins and prolactin by immunoradiometric assay and testosterone and estradiol by radioimmunoassay in adult male Wistar rats with cirrhosis induced by carbon tetrachloride. No significant difference in mean \pm SEM percentages of lactotrophs was found between cirrhotic animals and controls $(\mathrm{N}=12$, mean $18.95 \pm 1.29 \%)$. Although there was no significant difference between groups in mean serum levels of prolactin (control: $19.2 \pm 4 \mathrm{ng} / \mathrm{mL}$ ), luteinizing hormone (control: $1.58 \pm 0.43 \mathrm{ng} / \mathrm{mL}$ ), follicle-stimulating hormone (control: $19.11 \pm$ $2.28 \mathrm{ng} / \mathrm{mL}$ ), estradiol (control: $14.65 \pm 3.22 \mathrm{pg} / \mathrm{mL}$ ), and total testosterone (control: $138.41 \pm 20.07 \mathrm{ng} / \mathrm{dL}$ ), 5 of the cirrhotic animals presented a hormonal profile consistent with hypogonadism, all of them pointing to a central origin of this dysfunction. Four of these animals presented high levels of estradiol and/or prolactin, with a significant correlation between these two hormones in both groups $(r=0.54 ; P=0.013)$. It was possible to detect the presence of central hypogonadism in this model of cirrhotic animals. The hyperestrogenemia and hyperprolactinemia found in some hypogonadal animals suggest a role in the genesis of hypogonadism, and in the present study they were not associated with lactotroph hyperplasia.
\end{abstract}

Key words

- Hypogonadism

- Hyperestrogenemia

- Hyperprolactinemia

- Lactotrophs

- Liver cirrhosis

\section{Introduction}

In liver cirrhosis, a highly prevalent chronic disease, the gonadal axis is notably affected. There are reports of a prevalence of hypogonadism in 70 to $80 \%$ of cirrhotic patients (1) or even $89 \%$ in individuals with liver cirrhosis of different etiologies (2). The production of testosterone by cirrhotic individuals is, on average, $25 \%$ of that found in normal individuals (3). Low levels of this hormone are already noted even in ChildPugh A cirrhotic patients, and the decline is directly proportional to the degree of liver failure $(4,5)$.

In cirrhosis, hypogonadism can be pri- 
mary or central, resulting from the inhibition of the hypothalamus-pituitary-gonadal axis (6), with studies showing simultaneous (gonadal and central) damage (5,7). Most of the times, however, despite marked gonadal failure, serum levels of gonadotropins are low, indicating central involvement (8). Hyperprolactinemia is often present in these patients, as well as hyperestrogenemia, both responsible for the clinical characteristics of feminization. Hyperprolactinemia and hyperestrogenemia can contribute to the genesis of hypogonadism.

To the best of our knowledge, there are few clinical studies or experimental studies evaluating the histological behavior of the pituitary gland in cirrhosis. El Etreby and Gunzel (9), in an extensive review focusing on lactotrophs in the presence of exogenous and endogenous hyperestrogenemia, described isolated cases of lactotroph hyperplasia in cirrhotic human livers. In cirrhotic rats, a study failed to show altered serum or pituitary prolactin levels, but the immunohistochemical technique was not used for the evaluation of pituitary histology (10).

The aim of the present study was to evaluate the pituitary lactotrophs and the lactotropic and gonadotropic hormones in an animal model of carbon tetrachloride-induced liver cirrhosis.

\section{Material and Methods}

\section{Animals, drugs and procedures}

Adult male Wistar rats were housed in groups of 4 under controlled light/dark cycles (lights on from 7 am to $7 \mathrm{pm}$ ) and temperature $\left(22 \pm 4^{\circ} \mathrm{C}\right)$, and received standard rat chow (Purina-Nutripal, Porto Alegre, RS, Brazil) and water ad libitum. At the beginning of the experiment the mean age of the rats was 45 days and the mean weight $200 \mathrm{~g}$. The carbon tetrachloride (Merck, Rio de Janeiro, RJ, Brazil) was diluted at 1:7 in mineral oil (Schering, Rio de Janeiro, RJ,
Brazil). The animals submitted to carbon tetrachloride (group $1 ; \mathrm{N}=8$ ) received 0.5 $\mathrm{mL}$ of the solution intraperitoneally using disposable needles and syringes, once a day, with the first 10 doses administered every 5 days, next 10 doses every 4 days, and the last 5 doses every 3 days, for a total of 25 doses along 105 days of treatment. The control animals (group 2; $\mathrm{N}=12$ ) received $0.5 \mathrm{~mL}$ of mineral oil intraperitoneally using the same schedule adopted for the group of rats submitted to carbon tetrachloride. At the end of treatment the rats were decapitated, a trunk blood sample was obtained and the entire pituitary gland and the liver were rapidly removed.

\section{Morphological study of the liver}

The livers were placed in Bouin solution for $4 \mathrm{~h}$. The fragments were then washed in running water, transferred to flasks with $50 \%$ alcohol for $30 \mathrm{~min}$ and subsequently stored in $70 \%$ alcohol until being embedded in paraffin blocks. Three-micron thick slices were obtained from the paraffin blocks and the material was submitted to hematoxylineosin staining for routine histological evaluation, and to picrosirius for assessing the extent of liver fibrosis. The extent of fibrosis was graded as follows: mild, $25 \%$ of portal spaces affected; moderate, $25-75 \%$ of portal spaces affected; severe, more than $75 \%$ of portal spaces affected. A diagnosis of liver cirrhosis was defined when the extent of liver fibrosis of the animals was severe.

\section{Hormonal evaluation}

Prolactin (PRL), luteinizing hormone (LH) and follicle-stimulating hormone (FSH) levels were determined by immunoradiometric assay using liquid phase MAIAclone kits (Adaltis Italia S.p.A; Rome, Italy). The kits, originally designed for quantitative determination of these hormones in human serum, plasma or urine, were adapted for rat 
serum and plasma $(11,12)$. Standards, samples and controls were analyzed in duplicate in a single batch. In all assays, the coefficient of intra- and inter-assay variability was below $10 \%$. The minimum detectable concentration was established at $0.2 \mathrm{ng} / \mathrm{mL}$ for FSH, at $0.14 \mathrm{ng} / \mathrm{mL}$ for $\mathrm{LH}$ and at $0.5 \mathrm{ng} / \mathrm{mL}$ for PRL, which correspond to the concentrations obtained from the mean of 20 determinations in duplicate of the zero standard. The cross-reactions of FSH, LH and PRL were less than $0.56 \%$ for all hormones examined (FSH, LH, PRL, growth hormone, and thyroid-stimulating hormone). The accuracy of the assay was determined according to the values obtained for serum of control rats (Biocode-Hycel, Liège, Belgium), whose concentrations were previously known, and was $14.4,1.7$, and $16.3 \mathrm{ng} / \mathrm{mL}$ for $\mathrm{FSH}, \mathrm{LH}$, and PRL, respectively, considering controls ranges of 11.3-16.7, 1.0-2.2 and 10.4-20.2.

Circulating testosterone and estradiol levels were determined by radioimmunoassay using solid phase DPC-Medlab kits (Los Angeles, CA, USA) previously adapted for determination in rats $(13,14)$. The sensitivity of the testosterone assay was $10.0 \mathrm{ng} / \mathrm{mL}$, and intra-assay and inter-assay coefficients $<8 \%$. The sensitivity of the estradiol assay was $2.0 \mathrm{pg} / \mathrm{mL}$ and intra-assay and interassay coefficients were $<10 \%$.

Reference values used were the values found in the control group.

\section{Morphological study of the pituitary gland}

After resection, the whole pituitary gland was placed in $10 \%$ formalin for subsequent embedding in paraffin. Three-micron sections of the blocks were obtained and mounted on glass slides prepared with organosilane, for a total of 10 sequential sections from each block on separate slides. After drying, the sections were maintained at room temperature until the time for the immunohistochemical procedure, in which an anti-pro- lactin polyclonal primary antibody (Santa Cruz, Biotechnology, Santa Cruz, CA, USA) was used at $1 / 800$ dilution, followed by the avidin-biotin-peroxidase technique. Positive and negative controls were obtained from normal pituitaries. In the negative control, the primary antibody was replaced with normal horse serum.

One slide of each pituitary was selected by the same pathologist, using as a criterion the quantity of the material visualized by the immunohistochemical technique. The selected slides were examined by light microscopy using a reticulated lens at $400 \mathrm{X}$ magnification. At least 500 cells per slide per animal were evaluated, using as many fields as needed to reach this number. The number of lactotrophs is reported as a percentage of the total number of cells. Slides were read by three independent observers, and the final result reported is the mean as percentage.

\section{Statistical analysis}

Data are reported as means \pm SEM of $N$ values. The Student $t$-test was used to compare the groups. Differences were considered significant when $\mathrm{P}<0.05$. The MannWhitney test was used for the lactotroph count and the Spearman test was used to assess correlation between the data.

The present study was approved by the Ethics Committee on Animal Experimentation of Fundação Faculdade Federal de Ciências Médicas de Porto Alegre.

\section{Results}

All the animals in group 1 developed liver cirrhosis, whereas no animal in group 2 showed any alteration in liver histology at the end of the experiment.

It was not possible to perform immunohistochemical evaluation in one animal of the control group because of the small quantity of adequate material. The analysis of the percent lactotroph counts obtained by three 
observers did not show any significant difference between readings, permitting us to obtain a mean percentage of the three counts. The mean \pm SEM percentage of lactotrophs was $17.72 \pm 0.96 \%$ for cirrhotic rats and $18.95 \pm 1.29 \%$ for control rats. No significant difference in mean percentage of lactotrophs was found between groups.

The mean and the respective SEM of each hormone evaluated in both groups are presented in Table 1. There was no statistically significant difference between groups in any of the hormones evaluated. Serum hormone levels of each cirrhotic animal are presented in Table 2 .

No significant correlation was found between the percentage of lactotrophs and se-

Table 1. Serum hormone levels of the cirrhotic and control rats.

\begin{tabular}{lcc}
\hline & Cirrhotic rats $(\mathrm{N}=8)$ & Control rats $(\mathrm{N}=12)$ \\
\hline Testosterone $(\mathrm{ng} / \mathrm{dL})$ & $122.96 \pm 22.92$ & $138.41 \pm 20.07$ \\
$\mathrm{LH}(\mathrm{ng} / \mathrm{mL})$ & $1.53 \pm 0.23$ & $1.58 \pm 0.43$ \\
$\mathrm{FSH}(\mathrm{ng} / \mathrm{mL})$ & $18.27 \pm 5.13$ & $19.11 \pm 2.28$ \\
Prolactin $(\mathrm{ng} / \mathrm{mL})$ & $20.37 \pm 4.35$ & $19.2 \pm 4$ \\
Estradiol $(\mathrm{pg} / \mathrm{mL})$ & $19.81 \pm 5.27$ & $14.65 \pm 3.22$
\end{tabular}

Data are reported as means \pm SEM. $\mathrm{LH}=$ luteinizing hormone; $\mathrm{FSH}=$ folliclestimulating hormone. There were no statistical differences between the cirrhotic and control rats (Student $t$-test).

Table 2. Serum hormone levels of the cirrhotic rats.

\begin{tabular}{lccccc}
\hline Animals & $\begin{array}{c}\text { Testosterone } \\
(\mathrm{ng} / \mathrm{dL})\end{array}$ & $\begin{array}{c}\mathrm{LH} \\
(\mathrm{ng} / \mathrm{mL})\end{array}$ & $\begin{array}{c}\mathrm{FSH} \\
(\mathrm{ng} / \mathrm{mL})\end{array}$ & $\begin{array}{r}\text { Prolactin } \\
(\mathrm{ng} / \mathrm{mL})\end{array}$ & $\begin{array}{r}\text { Estradiol } \\
(\mathrm{pg} / \mathrm{mL})\end{array}$ \\
\hline 1 & 184.0 & 2.0 & 52.0 & 19.5 & 16.5 \\
$2^{\mathrm{a}, \mathrm{b}, \mathrm{c}}$ & 109.8 & 1.9 & 17.4 & 27.5 & 50.0 \\
$3^{\mathrm{a}, \mathrm{c}}$ & 103.0 & 1.5 & 6.0 & 13.0 & 30.5 \\
4 & 201.0 & 2.2 & 9.6 & 9.0 & 7.0 \\
$5^{\mathrm{a}, \mathrm{b}}$ & 47.0 & 0.9 & 22.3 & 42.5 & 14.0 \\
$6^{\mathrm{a}, \mathrm{b}, \mathrm{c}}$ & 50.1 & 0.2 & 15.2 & 30.0 & 24.5 \\
$7^{\mathrm{a}}$ & 85.1 & 1.9 & 11.0 & 5.5 & 5.0 \\
8 & 203.7 & 1.5 & 12.7 & 16.0 & 11.0 \\
\hline
\end{tabular}

Reference values used (means \pm SEM of serum hormone levels of the control group): testosterone (138.41 $\pm 20.07 \mathrm{ng} / \mathrm{dL})$, luteinizing hormone $(\mathrm{LH}, 1.58 \pm 0.43 \mathrm{ng} / \mathrm{mL})$, follicle-stimulating hormone (FSH, $19.11 \pm 2.28 \mathrm{ng} / \mathrm{mL})$, prolactin $(19.2 \pm 4 \mathrm{ng} / \mathrm{mL})$, and

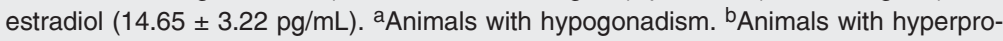
lactinemia. ${ }^{\mathrm{C} A n i m a l s}$ with hyperestrogenemia. rum levels of any of the hormones evaluated.

\section{Discussion}

Carbon tetrachloride has been recognized as an agent able to produce acute and chronic liver failure (15-17). This study used the protocol of cirrhosis induction modified by Rhoden et al. (18), whereby intraperitoneal $\mathrm{CCl}_{4}$ administration at lower doses and for longer than originally proposed allowed the development of liver cirrhosis in all treated animals, with no fatal losses, validating the method. To the best of our knowledge, there are no studies concomitantly evaluating histological behavior of lactotrophs by immunohistochemistry and presence of hypogonadism in an animal model of liver cirrhosis.

Ingleton et al. (10), in a study on male Wistar rats with $\mathrm{CCl}_{4}$-induced liver cirrhosis, did not find changes in pituitary or serum prolactin compared to a control group. In our study there were 3 cases (37.5\%) of hyperprolactinemia. The relationship between hyperprolactinemia and hyperestrogenemia has been described in cirrhosis, but the mechanisms determining hyperprolactinemia are unclear and literature data about the influence of estrogens in this context are controversial. Generally, a positive correlation between estrogenemia and prolactinemia is not found in cirrhosis $(19,20)$. There is evidence of altered hypothalamic regulation of prolactin secretion in cirrhosis, preferentially correlating hyperprolactinemia to an impaired balance between the neurotransmitters involved in its regulation (21-23). In the present study, there was a significant positive correlation between estradiol and prolactin in the cirrhotic and control groups but probably the direct stimulation of the pituitary by estradiol is only one of the factors determining hyperprolactinemia, with hypothalamic dysfunction probably being associated, as observed in hypogonadism. In support of this, there is evidence of estrogen 
receptors in the anterior hypothalamus, which could interfere on the regulation of prolactin secretion in these cases (24).

Most of the studies evaluating hypogonadism in liver cirrhosis point to a central origin of the dysfunction (25). In the present study, in the 5 animals with a hormonal profile consistent with hypogonadism, serum LH levels were inappropriately normal for the extent of gonadal failure, or even decreased, indicating central dysfunction. It should be emphasized that in some of these animals, estradiol and/or prolactin levels were increased. This allows us to consider that hyperprolactinemia, whether or not resulting from hyperestrogenemia, is at least partly responsible for the central origin of hypogonadism in our study, and that hyperestrogenemia per se may also be involved in the central mechanism of induction of hypogonadism.

The percentage of lactotrophs found in the control group was within the range previously reported for adult male Wistar rats, i.e., $10.5 \%$ (26), $15 \%$ (27), $21.7 \%$ (28), and $26 \%$ (29).

Three studies reporting histological evaluation of the pituitary gland in humans with cirrhosis have respectively described an increased number of acidophilic cells (which produce growth hormone and prolactin), confirmed by immunohistochemistry (30), a case in which the pituitary gland presented lactotroph hyperplasia evaluated by a second technique other than immunohistochemistry (9), linking this fact to associated hyperestrogenemia, and an increased number of lactotrophs, in the absence of immunohistochemical evaluation (31).

The fact that adequate methods for lactotroph characterization were used in the present investigation (immunohistochemistry) allows us to suggest that, in an animal model, hyperprolactinemia and hyperestrogenemia associated with cirrhosis do not parallel lactotroph hyperplasia, a fact corroborated by the lack of correlation between serum prolactin levels and the number of these cells. However, since only $50 \%$ of the cirrhotic rats developed hyperprolactinemia or hyperestrogenemia, the lack of effect on the number of the lactotroph cells must be confirmed by other studies.

In the experimental model of liver cirrhosis used here, hyperestrogenemia and/or hyperprolactinemia found in some hypogonadal animals were not associated with lactotroph hyperplasia, which suggests a hypothalamic disorder in the genesis of hypogonadism.

\section{References}

1. Fagiuoli S, De Maria N, Van Thiel DH. The liver and endocrine dysfunction. In: Becker KL (Editor), Principles and practice of endocrinology and metabolism. Philadelphia: J.B. Lippincot Company; 1995.

2. Oliveira MC, Cassal A, Pizarro CB. Avaliação do eixo hipotálamo hipófise-gônada e prevalência de hipogonadismo central em homens e mulheres com cirrose hepática. Arq Bras Endocrinol Metabol 2003; 47: 593-600.

3. Gelding SV, Alberti KGMM, Johnston DG. The liver and the endocrine system. In: Millward-Sadler GH, Wright R, Arthur MJP (Editors), Wrights liver and biliary disease. Philadelphia: WB Saunders Company; 1992.

4. Handelsman DJ, Strasser S, McDonald JA, Conway AJ, McCaughan GW. Hypothalamic-pituitary-testicular function in end-stage nonalcoholic liver disease before and after liver transplantation. Clin Endocrinol 1995; 43: 331-337.
5. Zietz B, Lock G, Plach B, Drobnik W, Grossmann J, Scholmerich J, et al. Dysfunction of the hypothalamic-pituitary-glandular axes and relation to Child-Pugh classification in male patients with alcoholic and virus-related cirrhosis. Eur J Gastroenterol Hepatol 2003; 15: 495-501.

6. Van Steenbergen W. Alcohol, liver cirrhosis and disorders in sex hormone metabolism. Acta Clin Belg 1993; 48: 269-283.

7. Cotrozzi G, Relly P, Meacci E, Smorlesi C, Strazzulla G, Brocchi A, et al. Pituitary-thyroid and pituitary-testis axes in liver cirrhosis. Boll Soc Ital Biol Sper 1987; 6: 513-516.

8. Bannister P, Handley T, Chapman C, Losowsky MS. Hypogonadism in chronic liver disease: impaired release of luteinising hormone. $\mathrm{Br}$ Med J 1986; 293: 1191-1193.

9. El Etreby MF, Gunzel P. Sex hormones - effects on prolactin cells. Acta Endocrinol Suppl 1974; 189: 1-15.

10. Ingleton PM, Rodgers GR, Faulkner M, Parsons MA. The pituitary in 
cirrhosis: ultrastructure, growth hormone, and prolactin concentrations. Exp Mol Pathol 1992; 56: 119-131.

11. Teerds KJ, Closset J, Rommerts FF, de Rooij DG, Stocco DM, Colenbrander B, et al. Effects of pure FSH and LH preparations on the number and function of Leydig cells in immature hypophysectomized rats. J Endocrinol 1989; 120: 97-106.

12. Reiter E, McNamara M, Closset J, Hennen G. Expression and functionality of luteinizing hormone/chorionic gonadotropin receptor in the rat prostate. Endocrinology 1995; 136: 917-923.

13. Ellis GB, Desjardins C. Male rats secrete luteinizing hormone and testosterone episodically. Endocrinology 1982; 110: 1618-1627.

14. Ortiz RM, Wade CE, Morey-Holton E. Urinary excretion of LH and testosterone from male rats during exposure to increased gravity: post-spaceflight and centrifugation. Proc Soc Exp Biol Med 2000; 225: 98-102.

15. Cremonese RV, Pereira-Filho AA, Magalhaes R, de Mattos AA, Marroni CA, Zettler CG, et al. Experimental cirrhosis induced by carbon tetrachloride inhalation: adaptation of the technique and evaluation of lipid peroxidation. Arq Gastroenterol 2001; 38: 40-47.

16. Frezza EE, Gerunda GE, Farinati F, DeMaria N, Galligioni A, Plebani $F$, et al. CCL4-induced liver cirrhosis and hepatocellular carcinoma in rats: relationship to plasma zinc, copper and estradiol levels. Hepatogastroenterology 1994; 41: 367-369.

17. Onori P, Morini S, Franchitto A, Sferra R, Alvaro D, Gaudio E. Hepatic microvascular features in experimental cirrhosis: a structural and morphometrical study in CCl4-treated rats. J Hepatol 2000; 33: 555-563.

18. Rhoden EL, Pereira-Lima J, Rhoden CR, Zettler CG, Barros EG. Modelo experimental de indução de cirrose hepática em ratos com tetracloreto de carbono. Gastrenterol Endoscopia Digest 1991; 10 : 149-152.

19. Relli P, Cotrozzi G, Meacci E, Smorlesi C, Guazzelli R, Brocchi A, et al. Plasma prolactin in liver cirrhosis. Boll Soc Ital Biol Sper 1987; 63: 517-520.

20. De Besi L, Zucchetta P, Zotti S, Mastrogiacomo I. Sex hormones and sex hormone binding globulin in males with compensated and decompensated cirrhosis of the liver. Acta Endocrinol 1989; 120: 271-276.
21. Us Zafar MS. Hypothalamus and pituitary gland. In: William SH, Schaffner F, Berck JE (Editors), Bockus gastroenterology. Philadelphia: WB Saunders Company; 1995.

22. Carlson HE. Pituitary function in systemic disorders. In: Melmed S (Editor), The pituitary. Ann Arbor: Blackwell Science; 1995.

23. Esquifino Al, Cano P, Jimenez V, Reyes Toso CF, Cardinali DP. Changes of prolactin regulatory mechanisms in aging: 24-h rhythms of serum prolactin and median eminence and adenohypophysial concentration of dopamine, serotonin, gamma-aminobutyric acid, taurine and somatostatin in young and aged rats. Exp Gerontol 2004; 39: 45-52.

24. Vician L, Shupnik MA, Gorski J. Effects of estrogen on primary ovine pituitary cell cultures: stimulation of prolactin secretion, synthesis, and preprolactin messenger ribonucleic acid activity. Endocrinology 1979; 104: 736-743.

25. Seehofer D, Steinmueller T, Graef KJ, Rayes N, Wiegand W, Tullius SG, et al. Pituitary function test and endocrine status in patient with cirrhosis of the liver before and after hepatic transplantation. Ann Transplant 2002; 7: 32-37.

26. Takahashi S, Kawashima S. Age related changes in prolactin cells in male and female rats of the Wistar/TW strain. $J$ Sci Hiroshima Univers 1983; 31: 185-191.

27. Ruitenberg EJ, Berkvens JM, van Nesselrooij JH. A histological study of the adenohypophysis of the rat. 2. A semiquantitative time sequence study. Z Versuchstierkd 1974; 16: 252-256.

28. Oliveira MC, Messinger HP, Tannhauser M, Barbosa-Coutinho L. Chronic effect of antidopaminergic drugs or estrogen on male Wistar rat lactotrophs and somatotrophs. Braz J Med Biol Res 1999; 32: 1561-1564.

29. Perez RL, Machiavelli GA, Romano MI, Burdman JA. Prolactin release, oestrogens and proliferation of prolactin-secreting cells in the anterior pituitary gland of adult male rats. J Endocrinol 1986; 108: 399-403.

30. Takanashi $\mathrm{R}$, Ishikawa $\mathrm{H}$. Increased acidophils of the hypophysis in liver cirrhosis. Acta Pathol Jpn 1984; 34: 67-75.

31. Jung $Y$, Russfield $A B$. Prolactin cells in the hypophysis of cirrhotic patients. Arch Pathol 1972; 94: 265-269. 